\title{
Adult glandular stem cells (GSCs): deciphering the future
}

\begin{abstract}
In the past decades, a huge progressively escalating international pool of information regarding stem cell research and their applications was periodically accumulating. Among the famous, well-established stem cell sources and lines, a new source appeared that was derived from the adult glands. Despite the long time theories speculating that adult glands, as most of adult tissues, harbor their own stem cells pool, only recently those cells were isolated, characterized and successfully propagated from the glands. Although some them are still in the immature phase of research, but within few years, the newly identified glands derived stem cell lines proved their potency in multiple fields, with the relative ease of their harvesting compared to other sources. For the first time in literature, a definitive focus is given in this review to the adult gland derived stem cells, in a trial to understand and track their potentials as a new innovative form of stem cells for future applications.
\end{abstract}

Volume 2 Issue 4 - 2015

Salem $\mathrm{H}$

Associate Lecturer of Plastic Surgery, Cairo University, Egypt

Correspondence: Salem H,Associate Lecturer of Plastic

Surgery, Cairo University, Egypt,

Email drsalemhaitham@gmail.com

Received: April 14, 2014 | Published: September 04, 2015

Keywords: glands, stem cells, regenerative medicine

Abbreviations: MSCs, mesenchymal stem cells; NSCs, neuronal stem cells; PSCs, pancreatic stem cells; BMCs, bone marrow-derived stem cells; FACS, fluorescent activated cell sorting; EMT, epithelial-mesenchymal transition

\section{Introduction}

In 1839 after Theodor Schwann launched the Cell Theory and since Rudulf Virchow adopted his famous slogan: Omnis cellula e cellula (All cells come from cells), Cell division was considered the most fundamental process in the development of living organisms. The generation of cell diversity throughout development, the multiplication of cells during wound repair and maintenance, the integrity of tissues and organs, all rely on the proper progress through cell division

Historically, The stem cell story begins with the recognition of the regenerative powers of the head of the Lernean Hydra and the human liver (Prometheus) by the ancient Greeks. ${ }^{1}$

For tissues and organs to maintain a balance between cell loss and replacement, cells should be capable of self-renewal as well as differentiation. At the heart of this process lie the functional units of regeneration; stem and progenitor cells, first described in $1964 .^{2}$

Stem cells are unspecialized cells that are characterized by; First: the ability for continuous division into daughter cells that have the same characteristics as the mother cells, this criterion is called Selfrenewal. Second: the ability of generating daughter cells that have different, more restricted properties than the original cell and can re-produce in turn, this is called Differentiation, Pluripotency or Plasticity. ${ }^{3,4}$ Meanwhile, a progenitor cell is generally considered a more intermediate cell between a stem cell and a differentiated cell. This partially specialized cell can divide and generate new differentiated cells (Figure 1).

The stem cell, the mother of all cells, is capable of differentiating across tissue lineage boundaries (Trans-differentiate) and is directly responsible for the generation and maintenance of diverse tissues in our bodies. ${ }^{6}$ Due to their expected limitless therapeutic potential, stem cells continue to be of a huge interest as they have many applications poised for clinical and preclinical trials, which will enable the potential of regenerative medicine to be realized. ${ }^{7-9}$

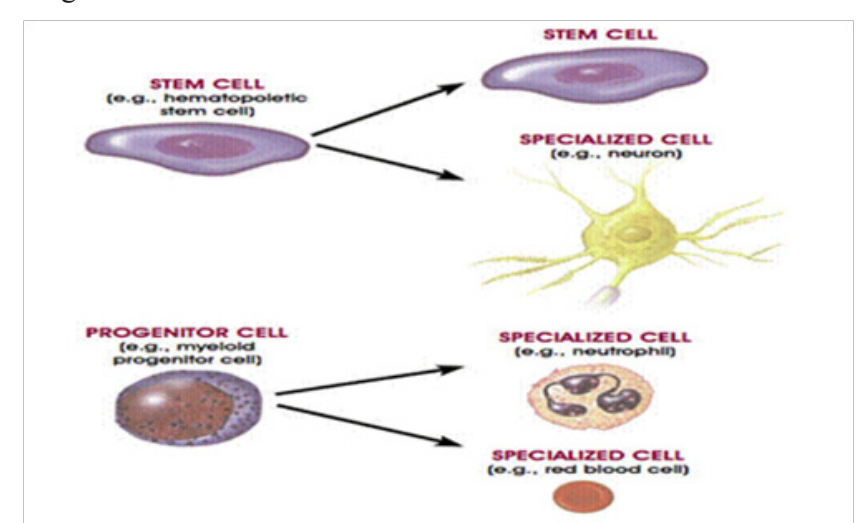

Figure I Distinguishing features of progenitor/precursor cells and stem cells.

Adult (non-embryonic, postnatal somatic) stem cell is an undifferentiated cell found among differentiated cells in a tissue or organ that has the ability to renew itself (Multipotency). ${ }^{10}$ Growing attention has focused on organ specific adult stem cells both to better understand how injured organs regenerate and as a therapeutic target for disease modulation. ${ }^{11,12}$ It was originally thought that the adult mammalian stem cells were only present in organs such as blood, skin, gut, testis and the respiratory tract, which have high cell turnover rates. It was proven, however, that most, if not all, adult organs contain stem cells, or at least can produce stem cells in culture. ${ }^{13,14}$

Adult stem cells derived from bone marrow have been used for more than 40years for treatment of hematological disorders. Since the identification of the first adult mouse bone marrow stem cell by McCulloch and till, and throughout the 1950s and 1960s, it was shown that transplantations of the Haemopoeitic stem cells (HSCs) isolated from the bone marrow, could reconstitute the depleted bone marrow following irradiation. ${ }^{15}$ 
Following this discovery, Friedenstein et al. ${ }^{16}$ noticed another cell type in bone marrow explants, initially called the fibroblast colonyforming cells, now referred to as Marrow-derived or Mesenchymal Stem Cells (MSCs). ${ }^{16}$ In contrast to HSCs, MSCs can be grown more easily and can differentiate into mesoderm-derived tissues while HSCs can re-constitute the haemopoeitic system. MSCs can be selectively grown into bone cells (osteocytes), ${ }^{17}$ fat cells (adipocytes) ${ }^{18}$ and cartilage cells (chondrocytes) ${ }^{19}$ which made them an attractive choice for bone and cartilage tissue engineering as autologous transplant..$^{20,21}$ Moreover, they are now considered a routine medical procedure in treating leukemia patients in addition to HSCs. ${ }^{22}$

The discovery of adult stem cells in the CNS was first inferred from the evidence of neuronal turnover in the olfactory bulb and hippocampus. ${ }^{23,24}$ This discovery of what was called afterwards Neuronal Stem cells (NSCS) in an organ that was previously thought to be largely immutable following embryogenesis, opened new avenues of investigation in regenerative medicine concerning the role of such stem cells in Parkinsonism and Alzheimer's disease. ${ }^{25,26}$

Such adult stem cells breakthrough gave them an advantage over embryonic stem cells (ESCs) due to the debatable ethical and scientific considerations that accompany the use of ESCs. ${ }^{27-29}$ In this review, we highlight some of the particularly promising sources of potent adult stem cells; the glandular tissues, elucidating their importance and future potentials in diseases management.

\section{Pancreas derived stem cells (PSCs)}

Pancreas is a unique organ with a closely integrated admixture of exocrine and endocrine tissues. In the view of the success of pancreatic islet transplantation trials specially after development of the Edmonton Protocol in 1990 and its publish in $2000,{ }^{30,31}$ betacell stem or progenitor cells were seen as a potential source for the preparation of transplantable insulin-producing tissue. ${ }^{32}$

Thus, several adult islet/beta-cell progenitors derived from pancreas, liver, and bone marrow, are being studied. ${ }^{33}$ Moreover, it was proven that pancreas have Pancreas-derived Multipotent Precursor cells PMPS as described by Seaberg that express both neural and pancreatic precursor markers. ${ }^{34}$ Possible progenitors have been hypothesized to reside within the pancreatic ductal epithelium,,$^{35}$ acinar tissue and/or pancreatic small cells. ${ }^{36}$

Although transplantation of islet grafts containing higher numbers of ductal epithelial cells results in better clinical outcome, ${ }^{37}$ several in vitro attempts to isolate beta-cell progenitors thought to reside within the human ductal and acinar epithelium have been inconsistent till today. ${ }^{38-41}$

Earlier, Choi et al..$^{42}$ followed by Seeberger et al..$^{43}$ proved that stem cells isolated from different parts of the adult pancreas are able to cross-lineage boundaries in vitro, in addition to its differentiation into endodermal and mesodermanl cells..$^{42,43}$ Also, the exocrine acinary part of the pancreas, particularly periacinary or dedifferentiated acinary cells, were considered to be other source of stem cells. ${ }^{44}$

Surprisingly after, Kruse et al. ${ }^{45}$ proved that cells isolated from the exocrine parts of adult pancreas have remarkable ability for selfrenewal together with great plasticity potential. These cells were able to differentiate into various cell types representing all three germ layers. Those cells demonstrated (i) typical stem/progenitor cell markers (Alk. Phos., SSEA-1, Oct-4, CD9, Nestin, Pax6, CD44, alpha-fetoprotien), (ii) have potenitial to differentiate into lineages of all three germ layers in vitro, (iii) clonal analysis revealed that even cell lines derived from single cell have stem/progenitor cell properties, (iv) external stimuli can activate the generation of certain cell types (e.g: alpha-smooth muscle actin upon retinoic acid stimulation). Those cells were called Pancreatic Stellate Cells based on their morphological appearance or more commonly Pancreatic Stem Cells (PSCs). ${ }^{45,46}$

In a study that compared two stem cell populations (Skin versus Pancreatic stem cells) concerning their phenotypic characterization, stem cell characteristics and differentiation across lineage boundaries, it was surprisingly proved that the Skin-derived human adult stem cells share many features with the Pancreatic-derived human stem cells which opened the gate on a new way of tackling those PSCs concerning their medical applications and potential role in skin regeneration and wound healing. ${ }^{47}$ In this view, those cells were successfully tested for their potentials in wound healing, ${ }^{48}$ and for their ability to enhance the wound vicinity vascularity. ${ }^{49}$ Also they were used for defective Myocardial tissue repair proving a superior intra-myocardial homing of PSCs in comparison to MSCs therapy. ${ }^{50}$

\section{Salivary glands stem cells}

Salivary glands are derived from the endoderm and the ectoderm participates in organogenesis. ${ }^{51}$ They consist of many cell types, including duct epithelium, acinar, mesenchymal, and neuronal cells. $^{52}$ Acinar cells secrete amylase into the digestive tract. This feature resembles the pancreatic exocrine system. Thus, Salivary glands have also been described as a source of stem cells in mice and rats following tissue damage $\mathrm{e}^{53,54}$ and there has been experimental evidence that stem cells can be isolated from intact, non damaged rat submandibular glands..$^{55}$ The existence of salivary gland stem cells has been postulated, although it remained unclear in which compartment of the gland the cells reside. Some authors suggested the intercalated ducts, whereas others favored the theory that MSCs are generally present in a perivascular niche. ${ }^{56}$

In 2008, Rotter et al ${ }^{57}$ published the first paper to describe the isolation and characterization of adult human stem cells from normal parotid gland, where they followed an amplification period of three to five passages. As a trial to salvage the function Salivary gland specially in patients with head and neck irradiation, Bone marrowderived stem cells (BMCs) were previously suggested as an easy accessible source for multipotent stem cells that could potentially transdifferentiate and/or repair other non-hematopoietic organs, ${ }^{58-61}$ including salivary glands. ${ }^{62}$

However, the use of BMCs in solid tissue repair is surrounded by controversies and the effects are limited. Transplantation of salivary gland stem cells was then proved to be a more adequate and elegant way to therapy after successful isolation of stem cells from both human Parotid and submandibular glands. ${ }^{63}$

Salivary gland cancers are relatively rare but constitute a highly significant public health issue due to the lack of effective treatments. In particular, patients with mucoepidermoid carcinoma or adenoid cystic carcinoma, the two most common salivary malignancies, have low long-term survival rates due to the lack of response to current therapies. Considering the role of Cancer Stem Cells in resistance to therapy in other tumor types, it is possible that this unique subpopulation of salivary gland stem cells is involved in resistance of salivary gland tumors to treatment. ${ }^{64} \mathrm{~A}$ deeper understanding of the underlying cellular biomechanics of the salivary glands and the 
potential of their stem cells may be a good option to treat post-tumors radiation-induced Xerostomia. ${ }^{65}$

Due to their large number and superficial distribution in the labial mucosa, Minor salivary glands were recently proposed as an easily accessible source of adult stem/progenitor cells for regenerative therapies of glandular organs with parenchymal pathology ${ }^{66}$ In a novel study, pulse chase strategy allowed the identification of slow cycling, label retaining cells (LRC) of minor salivary glands that preferentially localize in the basal layer of the lower excretory duct with a few in the acini possessing stem cells characteristics. Engraftment of isolated salivary glands LRC in vivo demonstrated their ability to differentiate into CK5 (basal layer marker) and CK8 (luminal layer marker) positive structures. ${ }^{67}$

Still, in the salivary glands research field, a single stem cell has not been identified that gives rise to all epithelial cell types within the gland. It is also not known whether a number of different lineagebiased stem cell populations or subtypes exist and how these differ from progenitor cells. ${ }^{68,69}$

\section{Sweat glands stem cells}

Skin is a readily accessible tissue for the isolation of adult autologous stem cells in contrast to most other tissues. The human body is covered with several million sweat glands. Two major types of sweat glands exist in the Human skin; eccrine and apocrine. The eccrine glands, which are widely distributed over the human body, have duct that opens onto the skin surface enabling the gland to secrete water and salt. In contrast, the apocrine sweat gland, which is present in hairy areas, is an appendage of the hair follicle and releases fluid through the follicle orifice. Moreover, apocrine sweat glands release an oily substance by shearing off cell parts as necrobiotic secretions. $^{70,71}$

Extensive Lineage tracing with transgenic mice lines has been used to track epithelial progenitors and their progeny. ${ }^{72,73}$ Recently, the existence of multipotent and unipotent progenitors in the sweat glands was proven using transgenic mice ${ }^{74}$ and through tracing the Nestin-positive multipotent stem cells directly isolated from human sweat glands specimens. ${ }^{75}$ Former studies using lineage tracing and mouse models proved the role of both the epidermis and the hair follicles stem cells in contribution to skin wound repair. ${ }^{76-80}$

Due to the abundance of sweat glands in relation to hair follicles in the majority area of human skin, it has been hypothesized that another source of progenitors or stem cells within the sweat apparatus (duct and gland) can contribute to skin wound repair. ${ }^{81-83}$

Interestingly, new mouse models permitted definitive assessment of the source of stem cell in wound healing process. Marked cells from the eccrine sweat ducts migrated upward to repair the epidermis within 3days after a superficial scratch wound. Intraepidermal sweat ducts were reconstructed within 2 weeks. Notably, these reconstructed ducts were derived from cells of the sweat apparatus and not epidermis. Moreover, only basal progenitors within sweat ducts, and not the secretory portion of glands, responded and proliferated to repairing the duct orifice after injury with sweating restoration. ${ }^{84}$ These results provide compelling evidence in support of the notion that the sweat duct is the growth center which repairs the ductal orifice extending through the epidermis to the skin surface. ${ }^{84}$

Another study readdressed this issue, but using the human skin By immuno histochemistry and computer-assisted three-dimensional reconstruction, researchers concluded that eccrine sweat glands contribute significantly to reepithelialization after partial-thickness wounds. This opens the gates for enormous wide range potential clinical applications, specially in cases of extensive burns and massive skin loss. ${ }^{85}$

In the last decade, in vivo transplantation had been used to assess the regenerative potential at a single-cell level for various ectodermal appendages as a trial for an innovative management of burns. Intriguingly, despite their unipotent behavior in the adult gland, when myoepithelial cells are purified from adult sweat glands, they recreate adult sweat glands. These findings suggest that myoepithelial cells retain multipotent (bipotent) potential that can be unleashed when challenged to de novo morphogenesis. ${ }^{84}$

\section{Mammary gland stem cells (MaSCs)}

Over 50years ago, researchers postulated the existence of multipotent mammary stem cells due to the fact that mammary epithelium is able to undergo multiple rounds of proliferation, differentiation and apoptosis with pregnancy. Experiments revealed that neither the developmental state nor reproductive history of the gland had a significant impact on the longevity of the mammary transplants. ${ }^{86,87}$

The study of mammary stem cell biology in the mouse actually began with the pioneering studies of Charles Deome and colleagues when serial transplantation of mammary tissue into the cleared mammary fat pad of syngenic mice was done ${ }^{88-90}$ They demonstrated that the adult mammary gland contained cells that were capable of reconstituting a complete and functional mammary gland with a normal ductal tree and hormonal response in the epithelium-divested fat pad of the transplant recipient. ${ }^{91}$

Subsequent studies demonstrated that cells capable of regenerating an entire mammary gland were present throughout the entire intact epithelial tree, and they persisted through various developmental states. ${ }^{92}$

A strategy was used to isolate MaSCs relied on a feature believed to be a key mechanism of DNA replication during stem cell division. During their division, certain adult stem cells preferentially retain one of their DNA strands throughout multiple divisions in order to protect against the formation of deleterious mutations that occur with replication. ${ }^{93,94}$ By performing pulse chase experiments with DNA labels, Smith et al. showed that there was a population of cells within the mammary gland, which retained their DNA label through asymmetric segregation of DNA strands. These cells were still actively dividing and featured stem cell characteristics. ${ }^{95}$

However, It was not until 2006 that self-renewing multipotent stem cells were isolated from the mammary gland by fluorescent activated cell sorting (FACS) to detect cell surface markers CD24 (heat stable integrin) and CD29 ( $\beta 1$-integrin) in mouse mammary tissue. ${ }^{96,97}$ CD49f ( $\alpha 6$-integrin) and EpCAM positive cells were then isolated from human mammary tissues..$^{98,99}$ The CD29 protein is not just a surrogate marker for MaSCs but is actually functionally important, as CD29 ablation in the basal compartment is reported to effectively reduce MaSC activity. ${ }^{100}$

Another study showed that with the use of a GFP reporter driven by the s-SHIP promoter, GFP+ replicating active MaSCs can be identified in cap cells at puberty and basal alveolar bud cells in pregnancy, but not in adult virgin animals, or in mammary tissues during lactation or involution stages. ${ }^{101}$ 
A major limitation of both the morphological and the label retention methods is that they do not allow easy isolation of large numbers of pure MaSC populations for use in in vitro or in vivo assays. ${ }^{102}$ With respect to the human mammary gland, identification of authentic MaSCs is considered a greater challenge due to the difficulty in obtaining normal tissue samples and the lack of an ideal in vivo reconstitution system. Nevertheless, various attempts have been made to characterize human MaSCs both in vitro and in vivo. ${ }^{103}$

As a trial to unravel this mystery with taking into consideration the analogous embryonic development of both mammary glands and sweat glands from ectodermal appendages, ${ }^{104}$ a latest study applied the already established isolation and propagation protocols used for salivary and sweat gland-derived stem cells, to the harvesting of MaSCs from the mammary tissue of female and male donors via adherence to conventional cell culture plastic, similar to the methods applied by Cregan et al. ${ }^{105}$ and colleagues for breast milk-derived stem cells, ${ }^{105}$ demonstrating a consistent isolation, propagation and identification of CK19+ nestin-positive MaSCs and with characterization of the cell populations derived from both genders. ${ }^{106}$

\section{Lacrimal gland derived stem cells}

A relatively new and particularly unique field of stem cells research due to the rarity of the in vitro human specimens for study. The lacrimal gland is made up of acini, ducts, nerves, myoepithelial cells, and plasma cells secreting a tear film interface between the external environment and the ocular surface. ${ }^{107}$ The majority, approximately $80 \%$, of the gland are the acinar cells, which secrete electrolytes, water, and proteins. ${ }^{108}$

Dry eye syndrome (DES) is caused by inadequate quantity or quality of tears. Although there are tear substitutes that can be used to temporarily lubricate the eye, there is no curative treatment for dry eye syndrome. ${ }^{109,110}$ Cell therapy involving replacement of the gland is a promising alternative for providing long-term relief to patients. ${ }^{111}$

Previously, Zoukhri et al. ${ }^{112}$ and Samantha et al. ${ }^{113}$ reported an increasing number of stem/progenitor cells present in the murine lacrimal gland during the repair phase after an experimentally induced inflammation. These cells were nestin positive, and some of them expressed $\alpha$-smooth muscle actin ( $\alpha$-SMA), suggesting a common source of stem cells between myoepithelial cells and acinar cells in the lacrimal gland..$^{12,113}$

Shortly afterwards, the same research group suggested that an Epithelial-Mesenchymal transition (EMT) is induced during repair of the lacrimal gland to generate Mesenchymal stem cells (MSCs) that migrate to the site of injury initiating repair, followed then by the activation of Mesenchymal-Epithelial Transition (MET) to form acinar and ductal epithelial cells with the contribution of several transcription factors (Snai1, Snai2, ZEB1 and ZEB2). ${ }^{114-116}$

While lacrimal gland cultures from animal sources are well established, ${ }^{117,118}$ similar evidence from humans is limited. Thus, a newly established study documented the first successful method of isolating and culturing functionally competent fresh human lacrimal gland cells using an enzyme cocktail of collagenase and hyaluronidase with Matrigel substrate. The established cultures were maintained in vitro for 30-35days, providing evidence for presence of putative stem cells in the tissues that express ABCG2 and ALDH1 stem cell markers. In addition, the cultures lead to the formation of spheres similar to the well documented Salispheres ${ }^{63}$ and Prostaspheres ${ }^{119}$ in their cellular organization. ${ }^{120}$ The discovery of stem cells in the lacrimal gland is an important finding on the path to salvage a damaged gland in the future.

\section{Future perspectives}

Due to expanding nature of the field and the accumulation of vast new information about them, there is an urgent growing need to focus separately on the adult gland-derived stem cells as a continuous supply of stem cells and to our knowledge; this is the first review that takes that matter into consideration. In contrast to embryonic stem cells (ESCs), the available different sources of adult gland derived stem cells raise less ethical concerns and are more readily available in the clinical routine with a very promising future potential for innovative management of diseases. Still, They are not fully understood regarding their mode of action, characters and long-term effects, which is yet to be investigated.

\section{Acknowledgements}

The Author would like to express all due respect to fellow colleagues at the Fraunhofer EMB, Germany. Also, all gratitude for the efforts, and the generous contribution of friends and colleagues at the KAFM, Cairo University, Egypt.

\section{Conflict of interest}

The author declares no conflict of interest.

\section{References}

1. Spyridonidis A, Zeiser R, Follo M, et al. Stem cell plasticity: the debate begins to clarify. Stem Cell Rev. 2005;1(1):37-43.

2. Lajtha LG, Gilbert CW, Porteous DD, et al. Kinetics of a Bone-Marrow Stem-Cell Population. Ann N Y Acad Sci. 1964;113:742-752.

3. Guillot PV, Cui W, Fisk NM, et al. Stem cell differentiation and expansion for clinical applications of tissue engineering. J Cell Mol Med. 2007;11(5):935-944.

4. Placzek MR, Chung IM, Macedo HM, et al. Stem cell bioprocessing: fundamentals and principles. J R Soc Interface. 2009;6(32):209-232.

5. Gupta S, Rosenberg ME. Do stem cells exist in the adult kidney? Am J Nephrol. 2008;28(4):607-613 .

6. Weissman IL, Anderson DJ, Gage F. Stem and progenitor cells: origins, phenotypes, lineage commitments, and transdifferentiations. Annu Rev Cell Dev Biol. 2001;17:387-403

7. Lemoli RM, Bertolini F, Cancedda R, et al. Stem cell plasticity: time for a reappraisal? Haematologica. 2005;90(3):360-381.

8. Riazi AM, Kwon SY, Stanford WL. Stem cell sources for regenerative medicine. Methods Mol Biol. 2009;482:55-90.

9. Kimbrel EA, Lu SJ. Potential clinical applications for human pluripotent stem cell-derived blood components. Stem Cells Int. 2011;2011:273076.

10. Metcalfe AD, Ferguson MW. Skin stem and progenitor cells: using regeneration as a tissue-engineering strategy. Cell Mol Life Sci. 2008;65(1):24-32.

11. Tumbar T, Guasch G, Greco V, et al. Defining the epithelial stem cell niche in skin. Science. 2004;303(5656):359-363.

12. Naveiras O, Daley GQ. Stem cells and their niche: a matter of fate. Cell Mol Life Sci. 2006;63(7-8):760-766.

13. Raff M. Adult stem cell plasticity: fact or artifact? Annu Rev Cell Dev Biol. 2003;19:1-22. 
14. Pelacho B, Mazo M, Gavira JJ, et al. Adult stem cells: from new cell sources to changes in methodology. $J$ Cardiovasc Transl Res. 2011;4(2):154-160.

15. Mathe G, Amiel JL, Schwarzenberg L, et al. Haematopoietic Chimera in Man after Allogenic (Homologous) Bone-Marrow Transplantation. (Control of the Secondary Syndrome. Specific Tolerance Due to the Chimerism). Br Med J. 1963;2(5373):1633-1635.

16. Friedenstein AJ, Deriglasova UF, Kulagina NN, et al. Precursors for fibroblasts in different populations of hematopoietic cells as detected by the in vitro colony assay method. Exp Hematol. 1974;2(2):83-92.

17. Ciavarella S, De Matteo M, Cafforio P, et al. Mesenchymal stem cells and bone regeneration. Recenti Prog Med. 200899(2):75-82

18. Schipper BM, Marra KG, Zhang W. Regional anatomic and age effects on cell function of human adipose-derived stem cells. Ann Plast Surg 2008;60(5):538-544 .

19. Xu J, Wang W, Ludeman M, et al. Chondrogenic differentiation of human mesenchymal stem cells in three-dimensional alginate gels. Tissue Eng Part A. 2008;14(5):667-680.

20. Noth U, Steinert AF, Tuan RS. Technology insight: adult mesenchymal stem cells for osteoarthritis therapy. Nat Clin Pract Rheumatol. 2008;4(7):371-380.

21. Wang TW, Wu HC, Wang HY, et al. Regulation of adult human mesenchymal stem cells into osteogenic and chondrogenic lineages by different bioreactor systems. J Biomed Mater Res A. 2009;88(4):935946

22. Liu K, Chen Y, Zeng Y, et al. Confusion of Mesenchymal Stromal Cells Facilitates Platelet Recovery Without Increasing Leukemia Recurrence in Haploidentical Hematopoietic Stem Cell Transplantation: A Randomized Controlled Clinical Study. Stem Cells Dev. 2011;20(10):1679-1685.

23. Altman J, Das GD. Autoradiographic and histological evidence of postnatal hippocampal neurogenesis in rats. $J$ Comp Neurol. $1965 ; 124(3): 319-335$

24. Altman J, Das GD. Autoradiographic and histological studies of postnatal neurogenesis.I. A longitudinal investigation of the kinetics, migration and transformation of cells incorporating tritiated thymidine in neonate rats, with special reference to postnatal neurogenesis in some brain regions. $J$ Comp Neurol. 1966;126(3):337-389.

25. Korecka JA, Verhaagen J, Hol EM. Cell-replacement and genetherapy strategies for Parkinson's and Alzheimer's disease. Regen Med. 2007;2(4):425-446.

26. Goldman SA. Disease targets and strategies for the therapeutic modulation of endogenous neural stem and progenitor cells. Clin Pharmacol Ther. 2007;82(4):453-460.

27. Frankel MS. In search of stem cell policy. Science. 2000;287(5457):1397.

28. Ida R. Ethical, legal and social issues in regenerative medicine. Nihon Rinsho. 2008;66(5):991-996.

29. Scott CT. Stem cells: new frontiers of ethics, law, and policy. Neurosurg Focus. 2008;24(3-4):E24.

30. Shapiro AM, Lakey JR, Ryan EA, et al. Islet transplantation in seven patients with type 1 diabetes mellitus using a glucocorticoid-free immunosuppressive regimen. $N$ Engl J Med. 2000;343(4):230-238.

31. Ryan EA, Lakey JR, Rajotte RV, et al. Clinical outcomes and insulin secretion after islet transplantation with the Edmonton protocol. Diabetes. 2001;50(4):710-719.

32. Liao YH, Verchere CB, Warnock GL. Adult stem or progenitor cells in treatment for type 1 diabetes: current progress. Can J Surg. 2007;50:137142
33. Lechner A, Habener JF. Stem/progenitor cells derived from adult tissues: potential for the treatment of diabetes mellitus. Am J Physiol Endocrinol Metab. 2003;284(2):E259-E266.

34. Seaberg RM, Smukler SR, Kieffer TJ, et al. Clonal identification of multipotent precursors from adult mouse pancreas that generate neural and pancreatic lineages. Nat Biotechnol. 2004;22(9):1115-1124.

35. Gao R, Ustinov J, Pulkkinen MA, et al. Characterization of endocrine progenitor cells and critical factors for their differentiation in human adult pancreatic cell culture. Diabetes. 2003;52(8):2007-2015.

36. Rooman I, Lardon J, Bouwens L. Gastrin stimulates beta-cell neogenesis and increases islet mass from transdifferentiated but not from normal exocrine pancreas tissue. Diabetes. 2002;51(3):686-690.

37. Street CN, Lakey JR, Seeberger K, et al. Heterogenous expression of nestin in human pancreatic tissue precludes its use as an islet precursor marker. J Endocrinol. 2004;180(2):213-225.

38. Zulewski H, Abraham EJ, Gerlach MJ, et al. Multipotential nestinpositive stem cells isolated from adult pancreatic islets differentiate ex vivo into pancreatic endocrine, exocrine, and hepatic phenotypes. Diabetes. 2001;50(3):521-533.

39. Street CN, Lakey JR, Shapiro AM, et al. Islet graft assessment in the Edmonton Protocol: implications for predicting long-term clinica outcome. Diabetes. 2004;53(12):3107-3114.

40. Zulewski H. Differentiation of embryonic and adult stem cells into insulin producing cells. Panminerva Med. 2008;50(1):73-79.

41. Yu L, Luo JX, Wei JL, et al. Insulin-Producing Acinar Cells in Adult Human Pancreas. Pancreas. 2014;43(4):592-596.

42. Choi Y, Ta M, Atouf F, et al. Adult pancreas generates multipoten stem cells and pancreatic and nonpancreatic progeny. Stem Cells. 2004;22(6):1070-1084

43. Seeberger KL, Dufour JM, Shapiro AM, et al. Expansion of mesenchyma stem cells from human pancreatic ductal epithelium. Lab Invest. 2006;86(2):141-153.

44. Jensen JN, Cameron E, Garay MV, et al. Recapitulation of elements of embryonic development in adult mouse pancreatic regeneration. Gastroenterology. 2005;128(3):728-741.

45. Kruse C, Kajahn J, Petschnik AE, et al. Adult pancreatic stem/progenitor cells spontaneously differentiate in vitro into multiple cell lineages and form teratoma-like structures. Ann Anat. 2006;188(6):503-517.

46. Danner S, Kajahn J, Geismann C, et al. Derivation of oocyte-like cells from a clonal pancreatic stem cell line. Mol Hum Reprod. 2007;13(1):1120 .

47. Kajahn J, Gorjup E, Tiede S, et al. Skin-derived human adult stem cells surprisingly share many features with human pancreatic stem cells. Eur J Cell Biol. 2008;87(1):39-46.

48. Salem H, Ciba P, Rapoport DH, et al. The influence of pancreasderived stem cells on scaffold based skin regeneration. Biomaterials. 2009;30(5):789-796

49. Egaña JT, Danner S, Kremer M, et al. The use of glandular-derived stem cells to improve vascularization in scaffold-mediated derma regeneration. Biomaterials. 2009;30(30):5918-5926.

50. Norbert Guldner W, Charli Kruse, Hans Sievers H. Glandular Stem Cells: A New Source for Myocardial Repair? Regenerative medicine and tissue engineering. 2011.

51. Larson WJ. Human Embryology. 3rd ed. UK: Churchill Livingstone; 2001.

52. Fawcett DW. A Textbook of Histology. 11th ed. USA: Saunders; 1986 p. 587-597. 
53. Okumura K, Nakamura K, Hisatomi Y, et al. Salivary gland progenitor cells induced by duct ligation differentiate into hepatic and pancreatic lineages. Hepatology. 2003;38(1):104-113.

54. Hisatomi Y, Okumura K, Nakamura K, et al. Flow cytometric isolation of endodermal progenitors from mouse salivary gland differentiate into hepatic and pancreatic lin- eages. Hepatology. 2004;39(3):667-675.

55. Kishi T, Takao T, Fujita K, et al. Clonal proliferation of multipotent stem/progenitor cells in the neonatal and adult salivary glands. Biochem Biophys Res Commun. 2006;340(2):544-552.

56. Da Silva Meirelles L, Chagastelles PC, Nardi NB. Mesenchymal stem cells reside in virtually all post- natal organs and tissues. $J$ Cell Sci. 2006;119(11):2204-2213.

57. Rotter N, Oder J, Schlenke P, et al. Isolation and characterization of adult stem cells from human salivary glands. Stem Cells Dev. 2008;17(3):509518 .

58. Couzin J. Clinical trials. A shot of bone marrow can help the heart. Science. 2006;313(5794):1715-1716.

59. Lagasse E, Connors H, Al-Dhalimy M, et al. Purified hematopoietic stem cells can differentiate into hepatocytes in vivo. Nat Med. 2000;6(11):1229-1234.

60. Nishida M, Fujimoto S, Toiyama K, et al. Effect of hematopoietic cytokines on renal function in cisplatin-induced ARF in mice. Biochem Biophys Res Commun. 2004;324(1):341-347.

61. Orlic D, Kajstura J, Chimenti S, Jakoniuk I, Anderson SM, et al. Bone marrow cells regenerate infarcted myocardium. Nature. 2001;410(6829):701-705.

62. Lombaert IM, Wierenga PK, Kok T, et al. Mobilization of bone marrow stem cells by granulocyte colony-stimulating factor ameliorates radiation-induced damage to salivary glands. Clin Cancer Res. 2006;12(6):1804-1812.

63. Lombaert IM, Brunsting JF, Wierenga PK, et al. Rescue of Salivary Gland Function after Stem Cell Transplantation in Irradiated glands. PLoS One. 2008;3(4):e2063.

64. Adams A, Warner K, Nör JE. Salivary gland cancer stem cells. Oral Oncol. 2013;49(9):845-853.

65. Pringle S, Van Os R, Coppes RP. Concise review: Adult salivary gland stem cells and a potential therapy for xerostomie. Stem Cells. 2013;31(4):613-619.

66. Andreadis D, Bakopoulou A, Leyhausen G, et al. Minor salivary glands of the lips:a novel, easily accessible source of potential stem/progenitor cells. Clin Oral Investig. 2014;18(3):847-856.

67. Zhang H, Boddupally K, Kandyba E, et al. Defining the localization and molecular characterisitic of minor salivary gland label retaining cells. Stem Cells. 2014;32(8):2267-2277.

68. Lombaert IM, Knox SM, Hoffman MP. Salivary gland progenitor cel biology provides a rationale for therapeutic salivary gland regeneration. Oral Dis. 2011;17(5):445-449.

69. Carpenter GH, Cotroneo E. Salivary gland regeneration. Front Oral Biol. 2010;14:107-128.

70. Sato K, Kang WH, Saga K, et al. Biology of sweat glands and their disorders. I. Normal sweat gland function. J Am Acad Dermatol. 1989;20(4):537-563.

71. Wilke K, Martin A, Terstegen L, et al. A short history of sweat gland biology. Int J Cosmet Sci. 2007;29(3):169-179.

72. Soriano P. Generalized lacZ expression with the ROSA26 Cre reporter strain. Nat Genet. 1999;21(1):70-71.
73. Blanpain C, Simons BD. Unravelling stem cell dynamics by lineage tracing. Nat Rev Mol Cell Biol. 2013;14(8):489-502.

74. Lu CP, Polak L, Rocha AS, et al. Identification of stem cell populations in sweat glands and ducts reveals roles in homeostasis and wound repair. Cell. 2012;150(1):136-150.

75. Nagel S, Rohr F, Weber C, et al. Multipotent nestin-positive stem cells reside in the stroma of human eccrine and apocrine sweat glands and can be propagated robustly in vitro. PLoS One. 2013;8(10):e78365.

76. Ito M, Liu Y, Yang Z, et al. Stem cells in the hair follicle bulge contribute to wound repair but not to homeostasis of the epidermis. Nat Med. 2005;11(12):1351-1354.

77. Levy V, Lindon $\mathrm{C}$, Zheng $\mathrm{Y}$, et al. Epidermal stem cells arise from the hair follicle after wounding. FASEB J. 2007;21(7):1358-1366.

78. Tiede S, Kloepper JE, Bodò E, et al. Hair follicle stem cells: walking the maze. Eur J Cell Biol. 2007;86(7):355-376.

79. Nowak JA, Polak L, Pasolli HA, et al. Hair follicle stem cells are specified and function in early skin morphogenesis. Cell Stem Cell. 2008;3(1):33-43.

80. Snippert HJ, Haegebarth A, Kasper M, et al. Lgr6 marks stem cells in the hair follicle that generate all cell lineages of the skin. Science. 2010;327(5971):1385-1389.

81. Brouard M, Barrandon Y. Controlling skin morphogenesis: Hope and despair. Curr Opin Biotechnol. 2003;14(5):520-525.

82. Biedermann T, Pontiggia L, Böttcher-Haberzeth S, et al. Human eccrine sweat gland cells can reconstitute a stratified epidermis. J Invest Dermatol. 2010;130(8):1996-2009.

83. Pontiggia L, Biedermann T, Böttcher-Haberzeth S, et al. De Novo Epidermal Regeneration Using Human Eccrine Sweat Gland Cells: Higher Competence of Secretory over Absorptive Cells. J Invest Dermatol. 2014;134(6):1735-1742.

84. Lu C, Fuchs E. Sweat gland progenitors in development, homeostasis, and wound repair. Cold Spring Harb Perspect Med. 2014:4(2).

85. Rittié L, Sachs DL, Orringer JS, et al. Eccrine sweat glands are major contributors to reepithelialization of human wounds. Am J Pathol. 2013;182(1):163-171.

86. Daniel CW, Young LJ, Medina D, et al. The influence of mammogenic hormones on serially transplanted mouse mammary gland. Exp Gerontol. 1971;6(1):95-101.

87. Young LJ, Medina D, DeOme KB, et al. The influence of host and tissue age on life span and growth rate of serially transplanted mouse mammary gland. Exp Gerontol. 1971;6(1):49-56.

88. Deome K, Faulkin LJ, Bern H, et al. Development of mammary tumors from hyperplastic alveolar nodules transplanted into gland-free mammary fat pads of female C3H mice. Cancer Res. 1959;19(5):515520 .

89. Faulkin LJ Jr, Deome KB. Regulation of growth and spacing of gland elements in the mammary fat pad of the $\mathrm{C} 3 \mathrm{H}$ mouse. J Natl Cancer Inst. 1960;24:953-969.

90. Daniel CW, Deome KB. Growth of mouse mammary glands in vivo after monolayer culture. Science. 1965;149(3684):634-636.

91. Robert D, Bruno, Gilbert H. Smith Reprogramming non-mammary and cancer cells in the developing mouse mammary gland. Semin Cell Dev Biol. 2012;23(5):591-598.

92. Smith GH, Medina D. A morphologically distinct candidate for an epithelial stem cell in mouse mammary gland. J Cell Sci. 1988;90(Pt 1):173-183. 
93. Cairns J. Somatic stem cells and the kinetics of mutagenesis and carcinogenesis. Proc Natl Acad Sci U S A. 2002;99(16):10567-10570.

94. Potten CS, Owen G, Booth D. Intestinal stem cells protect their genome by selective segregation of template DNA strands. J Cell Sci. 2002;115(Pt 11):2381-2388.

95. Smith GH. Label-retaining epithelial cells in mouse mammary gland divide asymmetrically and retain their template DNA strands. Development. 2005;132(4):681-687.

96. Shackleton M, Vaillant F, Simpson KJ, et al. Generation of a functional mammary gland from a single stem cell. Nature. 2006;439(7072):84-88.

97. Stingl J, Eirew P, Ricketson I, et al. Purification and unique properties of mammary epithelial stem cells. Nature. 2006;439(7079):993-997.

98. Eirew P, Stingl J, Raouf A, et al. A method for quantifying normal human mammary epithelial stem cells with in vivo regenerative ability. Nat Med. 2008;14(12):1384-1389.

99. Macias H, Hinck L. Mammary Gland Development. Wiley Interdiscip Rev Dev Biol. 2012;1(4):533-557.

100. Taddei I, Deugnier MA, Faraldo MM, et al. Beta1 integrin deletion from the basal compartment of the mammary epithelium affects stem cells. Nat Cell Biol. 2008;10(6):716-722.

101. Bai L, Rohrschneider LR. s-SHIP promoter expression marks activated stem cells in developing mouse mammary tissue. Genes Dev. 2010;24(17):1882-1892.

102. Tiede B, Kang Y. From milk to malignancy: the role of mammary stem cells in development, pregnancy and breast cancer. Cell Res. 2011;21(2):245-257.

103. Fan Y, Chong YS, Choolani MA, et al. Unravelling the mystery of stem/ progenitor cells in human breast milk. PLoS One. 2010;5(12):e14421.

104. Mustonen T, Ilmonen M, Pummila M, et al. Ectodysplasin A1 promotes placodal cell fate during early morphogenesis of ectodermal appendages. Development. 2004;131(20):4907-4919.

105. Cregan MD, Fan Y, Appelbee A, et al. Identification of nestin-positive putative mammary stem cells in human breastmilk. Cell Tissue Res. 2007;329(1):129-136.

106. Anja Richter, Nicole Nissen, Peter Mailänder, et al. Mammary glandderived nestin-positive cell populations can be isolated from human male and female donors. Stem Cell Res Ther. 2013;4(4):78.
107. Tiffany JM. The normal tear film. Dev Ophthalmol. 2008;41:1-20.

108. Dartt DA. Review Neural regulation of lacrimal gland secretory processes: relevance in dry eye diseases. Prog Retin Eye Res. 2009;28(3):155-177.

109. Schaumberg DA, Sullivan DA, Dana MR. Epidemiology of dry eye syndrome. Adv Exp Med Biol. 2002;506(Pt B):989-998.

110. Gupta N, Prasad I, Himashree G, et al. Prevalence of dry eye at high altitude: a case controlled comparative study. High Alt Med Biol. 2008;9(4):327-334.

111. Tiwari S, Ali MJ, Balla MM, et al. Establishing Human Lacrimal Gland Cultures with Secretory Function. PLoS One. 2012;7(1):e29458.

112. Zoukhri D, Fix A, Alroy J, et al. Mechanisms of murine lacrimal gland repair after experimentally induced inflammation. Invest Ophthalmol Vis Sci. 2008;49(10):4399-4406.

113. You S, Kublin CL, Avidan O, et al. Isolation and Propagation of Mesenchymal Stem Cells from the Lacrimal Gland. Invest Ophthalmol Vis Sci. 2011;52(5):2087-2094.

114. Thiery JP, Acloque H, Huang RY, et al. Review Epithelial-mesenchymal transitions in development and disease. Cell. 2009;139(5):871-890.

115. Franco DL, Mainez J, Vega S, et al. Snaill suppresses TGF-betainduced apoptosis and is sufficient to trigger EMT in hepatocytes. $J$ Cell Sci. 2010;123(Pt 20):3467-3477.

116. You S, Avidan O, Tariq A, et al. Role of Epithelial-Mesenchymal Transition in Repair of the Lacrimal Gland after Experimentally Induced Injury. Invest Ophthalmol Vis Sci. 2012;53(1):126-135.

117. Rismondo V, Gierow JP, Lambert RW, et al. Rabbit lacrimal acinar cells in primary culture: morphology and acute responses to cholinergic stimulation. Invest Ophthalmol Vis Sci. 1994;35(3):1176-183.

118. Ueda Y, Karasawa Y, Satoh Y, et al. Purification and characterization of mouse lacrimal gland epithelial cells and reconstruction of an acinarlike structure in three-dimensional culture. Invest Ophthalmol Vis Sci. 2009;50(5):1978-1987.

119. Shi X, Gipp J, Bushman W. Anchorage-independent culture maintains prostate stem cells. Dev Biol. 2007;312(1):396-406.

120. Tiwari S, Ali MJ, Vemuganti GK. Vemuganti, Human lacrimal gland regeneration: Perspectives and review of literature. Saudi J Ophthalmol. 2014;28(1):12-18. 